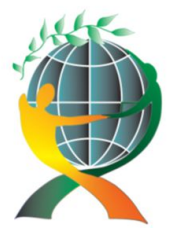

\author{
(online) $=$ ISSN $2285-3642$ \\ ISSN-L = $2285-3642$ \\ Journal of Economic Development, Environment and People \\ Volume 8, Issue 1, 2019 \\ URL: http://jedep.spiruharet.ro \\ e-mail: office jedep@spiruharet.ro
}

\title{
A Triple Layer Model to Manage Romania's Health Risks and Educational Consequences
}

\author{
Dr. Elena-Iuliana Paşcu-Gabără'1), Dr. Larisa Mihoreanu ${ }^{2)}$ \\ 1) Sanamed Hospital, Bucharest, Romania, ${ }^{2)}$ ANMDM/King's College London, UK
}

\begin{abstract}
This article explores the relationship between education and health from the perspective of revised literature and suggests an exercise combining the scientific theory with applied knowledge to achieve health progress reflected in health indices improvement for individuals and community. The relation between aggregate health condition, food and nutrition receives, through education, a new shape implying a three-way causality analysis to highlight the role of each entity exerting significant influences in the others' good functioning.

Three important issues are considered for the new and comprehensive definition: a) high level of education implies specific health benefits; $b$ ) health affects the level of education of the population; and c) living conditions, especially the childhood, affect both the population's education and the aggregate health of the whole nation.

This paper develops the new model to easier identify health risks, from the individuals' attitude and their behaviour in society, throughout life, within the institutional contexts.

The conclusion shows that individuals and their personal traits are built, shaped and solidified within the first social frame (family), being permanently affected by surroundings. Subsequently, the influence of the community - through consolidation, or disruptive factors - emphasized by political decisions, public establishments and their policies or other institutions - generates different social and cultural contexts whose aggregate consequences will be lasting and influence the national future.
\end{abstract}

Keywords: Food security, education, model, indicators.

JEL Codes: I30, I32, F60, D69

How to cite: Paşcu-Gabără, E., \& Mihoreanu, L. (2019). A Triple Layer Model to Manage Romania's Health Risks and Educational Consequences. Journal of Economic Development, Environment and People, 8(1), 29-37. doi:http://dx.doi.org/10.26458/jedep.v8i1.617

\section{Introduction}

The today society perceives the health outcomes as profoundly influenced by a variety of social factors that do not intrinsically belong to the health or care systems. The major differences in morbidity, mortality and risk factors, in a given geographic territory, are modelled within the classical social determinants of health: $\bullet$ the access to education, $\bullet$ the incomes, $\bullet$ the economic and social characteristics of whereabouts people live, $\bullet$ the existing public policies that govern people future shape. The World Health Organization (WHO) statistical data show that people with a lower level of education have a shorter life expectancy than those with higher degrees of education. 


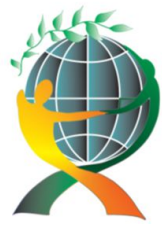

\author{
(online) $=$ ISSN $2285-3642$ \\ ISSN-L = $2285-3642$ \\ Journal of Economic Development, Environment and People \\ Volume 5, Issue 2, 2016
}

URL: http://jedep.spiruharet.ro

e-mail: office jedep@spiruharet.ro

Financial Express (Apr. 2018). The explanation of a shorter life resides in the very close relationship between poverty, food, nutrition and education (Gheorghiu, 2018). The unequal access to healthcare is also closely linked to the level of education reflecting in life expectancy differences, especially in those countries that report high school dropout (WHO/FE, 2018).

The latest report "Health at a Glance" (2018), published by the Organization for Economic Cooperation and Development (OECD) and the European Commission, cites the socio-ecological factors near the deficiencies in the health system and the unhealthy behaviours of the population as basic explanations regarding the unfortunate position of Romania in the hierarchy of European countries compared in the mentioned study. The report documents the health status of citizens and the health systems performances within the European Union countries - quantified by age, gender, ethnic and racial categories and different social groups in terms of life expectancy, the main causes of death, the social and health inequalities and the prevalence of non-communicable diseases (OECD, 2018).

A particular attention is paid to the substantial multi-criteria health-related discrepancies presented in the EU countries and summarized through statistics.

In Romania, the life expectancy reported represents less than 78 years for women and 73 years for men, while the EU average is 81 years and even 83 years in Spain and Italy (OECD, 2018). The analysis of age differences by gender shows that women averagely live five and a half years longer than men do; the data varies across geographic areas and regions, with life expectancy sometimes varying by up to 10 years (OECD, 2018).

The geographic disparities are also sizeable in the analysis of other health-related items and health education: infant mortality, food quality, obesity and diabetes prevalence, cardiovascular disease and other chronic diseases. Regardless of regional locations, these inequalities are caused mainly by the socioeconomic status, by the influence of cultural traditions in early childhood education, by the level of education.

The educational level (especially the one dominated by maternal transmission instincts) has been identified as a major predictor of health outcomes, and economic trends in the industrialized world have intensified the relationship between education and health. (Zimmerman et al, 2015).

Thus, this paper follows the direction of exploring the relation between education and health united by the topics of food and safety. It starts with the perspective of the revised literature, suggests a political modelling exercise as a useful tool for people working in public administration, in health education to merge the past practices and analyses with this new approach to improve the demographic health, food security and wellbeing for individuals and community sake.

Understanding the complex link between education and health and the reasons of studying differently their relation, do not represent a simple approach or only a new theoretical model. It is also a new pattern to analyze the socio-economic and political priorities, a challenge of a critical need to address the depths of social inequality in order to understand better health inequalities.

The awareness of the importance of education will help to improve the completely educational system by extrapolating the implementation of a long-run health education policy, based on nutrition and food security and risks, by stimulating robust investments in education in general and in health education in particular. 


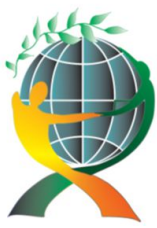

\author{
(online) $=$ ISSN $2285-3642$ \\ ISSN-L = $2285-3642$ \\ Journal of Economic Development, Environment and People \\ Volume 8, Issue 1, 2019
}

URL: http://jedep.spiruharet.ro

e-mail: office jedep@spiruharet.ro

\title{
2. A new definition of the Edu-health concept
}

The socio-medical-economic model is meant to identify, manage and adjust the health risks starting with a more concrete definition of the relationship between the level of education and the health status of a community based on individuals as the basic component units. We identify the education-health relationship as a causal perpetuum mobile, pointing the food conditions and quality as a main driver influencing and conducting the good functioning of the others.

As shown in table no. 1, there are three aspects to be taken into account for the complete and comprehensive definition of the above mentioned relation: a) a high level of education implies additional health benefits; b) health affects the population education level; and c) the living conditions, the childhood habits, the food and nutrition affect both the health and the level of education of the population (CSH, 2015).

Table no. 1. The causal relationship between health and education

\begin{tabular}{|l|}
\hline 1. Health benefits gained from life safety through adequate education and nutrition \\
\hline Health behaviours \\
-Accumulation of knowledge, skills, capabilities and abilities \\
- Change the lifestyle, introduce active living principles apply knowledge into the daily behaviour \\
\hline Social and psychological benefits \\
- Eliminating insecurity, reducing stress \\
- $\quad$ Accumulation of societal expertise and psychological cleverness and frame of mind \\
\hline Incomes, resources, perspectives \\
- $\quad$ More and better jobs, improved positions of employment \\
- $\quad$ Resourger and more diversified incomes \\
\hline 2. Poor health affects the level of education of the population (Ashraf, 2018) \\
\hline - Inappropriate nutrition, limited access to resources, ignoring individual and social diet tips \\
- Decreased concentration and learning difficulties \\
\hline 3. $\quad$ Living conditions affect health through poor diet and low level of education \\
\hline - $\quad$ Contextual factors \\
- Lack of realistic understanding of the situation at societal level \\
- Lack of skills in using the institutional and administrative tools provided by market and society to improve \\
the current situation \\
- Lack of practice in writing correct public policies and administrative procedures and standards for a \\
correct implementation, evaluation and monitoring \\
- Individual / family features with mutations over time, with individual and national influences (Ashraf et al. \\
2018)
\end{tabular}

The health benefits could be gained from life safety through adequate education and nutrition:

Accumulation of knowledge, capabilities and skills: The higher education people receive the better and healthier behaviour they learn and apply (CSH, 2015). This happens given a higher receptivity against prevention campaigns, better knowledge of their rights for the periodical health screenings, a deeper knowledge of their health needs helps the easy follow of the prescriber's recommendation, understand the need for a plan recovery, communicate effectively with medical staff (Goldman, 2002). Education is at the 


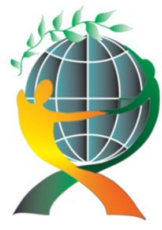

\author{
(online) $=$ ISSN $2285-3642$ \\ ISSN-L = $2285-3642$ \\ Journal of Economic Development, Environment and People \\ Volume 5, Issue 2, 2016 \\ URL: http://jedep.spiruharet.ro \\ e-mail: office jedep@spiruharet.ro
}

head of changes in beliefs, knowledge and healthy styles. Skills acquired through education sustains the health (through better incomes) an exert influence on the health status (through the ability to follow health regimes and manage illnesses, adapt to the functioning of a health system (Goldman, 2002).

Eliminate the uncertainty and reduce the stress: People with higher education - and hence higher incomes - miss often the stress caused by economic and financial difficulties, which the low-educated population has because of their needed resources to survive (Mc Ewen Stellar, 1993). The lifetime changes and trauma, the inflation, the discrimination, all are sources causing stress and consequently affect health. Over time, the economic difficulties and other stressors can have cumulative, negative effects on health, predisposing individuals to permanent diseases such: asthma, cardiovascular disease, gastrointestinal disorders and infections, all associated with higher rates of mortality in the elderly (Karlamangla et al, 2006).

Accumulation of societal expertise and psychological cleverness and frame of mind: The deep the formal knowledge, the more diverse the skills developed - cognition, observation, comparison, critical thinking, problem solving. This assists and encourages the key personality traits development. Education can increase "the learning efficiency", including cognitive skills, self-control and problem solving (Palczyńska and Świst, 2018). Key personality traits are successfully associated with education, employment and lower mortality rates (Palczyńska and Świst, 2018).

Adherence to healthy social networks that facilitate the personal development and social involvement: The social networks improve the access to information and exposure to peers who shape acceptable behaviours. The relationship between social support and education may be due in part to social and cognitive skills and greater involvement of civic groups and organizations that come with education (Berkman, 1995). A low social support is associated with higher rates of mortality and impaired mental health.

More and better jobs, improved positions of employment:

While a better educated person that applies for a vacancy is more likely to be employed and get a job with additional health benefits provided (health insurance, paid leave and retirement benefits), individuals who abandoned the school are more likely to have difficulties in finding jobs, working in risky domains, without benefits at all.

More diversified and higher income: Through its results, the education influences and ranks the health inequalities as a major component of the socio-economic status. Its variables help to measure the socioeconomic realities, influencing both health and longevity. When referring to the differences between education and longevity, many socio-economic variables - income, occupation, access to Medicare - are directly or indirectly related to education (Kaplan et al., 1994). Both the education and the socio-economic status of a person always show connections with income and wealth, with the social position and the role inside the community, pointed out through statistical data proved by life expectancy for all genders, races or ages (Olshansky et al., 2012).

The assets of a good health and a higher societal safety: Households built on high incomes prefer the healthier food, exercise regularly, and afford to pay extra services of care and wellbeing. At the other end, the jobs insecurity, the lack of material and emotional resources caused by lack of achievement and performance in the professional background make people (and their families) more vulnerable, especially in difficult times. This reverberates in inappropriate nutrition, unstable housing, and unsatisfied medical needs (Sobolewski and Amato, 2012). Lower incomes and lack of adequate coverage of insurance represent barriers to meeting health care needs. Access to care also affects the provision of preventive services and care for chronic diseases. 


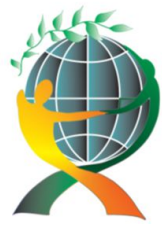

\author{
(online) $=$ ISSN $2285-3642$ \\ ISSN-L = $2285-3642$ \\ Journal of Economic Development, Environment and People \\ Volume 8, Issue 1, 2019 \\ URL: http://jedep.spiruharet.ro \\ e-mail: office jedep@spiruharet.ro
}

Health is affected by inadequate nutrition and also affects the level of education of the population:

Inappropriate nutrition, limited access to restricted resources, decreased concentration capacity: The relationship between education and health is complex, with multiple bio-psycho-social aspects, influenced by multiple drivers among which the childhood conditions of living and the nutrition are essential. Hence, patients with chronic childhood onset often have behavioural difficulties in class, lack of concentration, aggressiveness or prefer isolation, low esteem and self-respect for their body, for their knowledge.

Decreased capacity to concentrate and learning difficulties: Health conditions, disabilities and unhealthy behaviours can have, partially or cumulatively, dramatic effects on educational outcomes.

Depression, loss of self-esteem, social isolation and school dropout: The young people with continuous poor results at school never go farther. They prefer to abandon the school and colleagues than fight for a better position in the class. This often cause severe educational trauma that will later interfere with the mental health as well. For example, when compared to other students, patients with Attention Deficit / Hyperactivity Disorder (ADHD) are three times more likely to drop out school before graduation (Barbaresi et al., 2007). Disabilities could also affect school performance due to visual, hearing, attention difficulties, inadequate behaviour, absenteeism or limited cognitive abilities. Researches show that chronic pain, inappropriate nutrition, psychoactive substance use and smoking at an early age, infantile obesity, sleep disturbances, impaired mental health, asthma, visual disturbances and attention deficit or hyperactivity have established links with school performance diminished (Suhrcke and de Paz Nieves, 2011). Although the health impact on education (reverse causality) is important, it has often been questioned the extent of the role it plays.

Living conditions affect equally the health and the education level:

The relationship between the level of education and the health status can also be defined by the analysis of living conditions - traditions, family values and habits transferred to children during their early childhood as eating, behavioural habits. The family living conditions, the household socio-economic status, along with other negative contextual factors can create stress and cause the chronic conditions development, children and families deprivation of necessary social resources: school attendance, jobs with major benefits, the acquisition of a healthy life (Barbaresi et al., 2017).

Contextual factors can affect people's education and health along their entire life. The influence of biological characteristics, the socio-economic and environmental conditions - poverty, lack of knowledge of organizing the budget, deepening of material shortages - appear to be particularly important in early childhood. In that period of life, the physical health of children and academic success is also influenced by biological risk factors: low birth weight, congenital or chronic conditions (Conti and Heckman, 2010) and socio-economic status (e.g. education and property of parents).

The early childhood is more important as it is the period when the principles of health and education are modelled on the children's living environment, parent involvement in the robust physical and mental stimulation through educational activities fostering the development of social skills, the development of emotional intelligence, and learning abilities (Barnett, Steven and Belfield, 2006).

\title{
3. Socio-medical-economic model - Theoretical premise
}

Starting from the individual's position in society and his/her behavioural pathway in society, we have created a new theoretical model that allows the identification of lifelong health risks in a context of institutional contexts (Smedley and Syme, 2000). 


\author{
(online) = ISSN $2285-3642$ \\ ISSN-L = 2285 - 3642 \\ Journal of Economic Development, Environment and People \\ Volume 5, Issue 2, 2016
}

URL: http://jedep.spiruharet.ro

e-mail: office jedep@spiruharet.ro

The individual and personal traits are located within the family (the first social setting), affected by the context, and subsequently influenced by the community and its institutions (for example, school and group of friends, workplace and civil institutions) and policies of society in a wider social and cultural context (Figure 1).

Each element provides access to new opportunities, constraints and risks due to each one's actions. In addition, these levels interact with each other so that family resources mediate or influence available resources within the community. Considering that sociologists agree that unequal social status creates unequal access to resources and rewards, we extrapolate the idea of access to education and health services. The individual values are visible through the personal behaviour, actions becoming part of the community assets and structures, affecting influences, relations and mediations between different domains such as health and education.

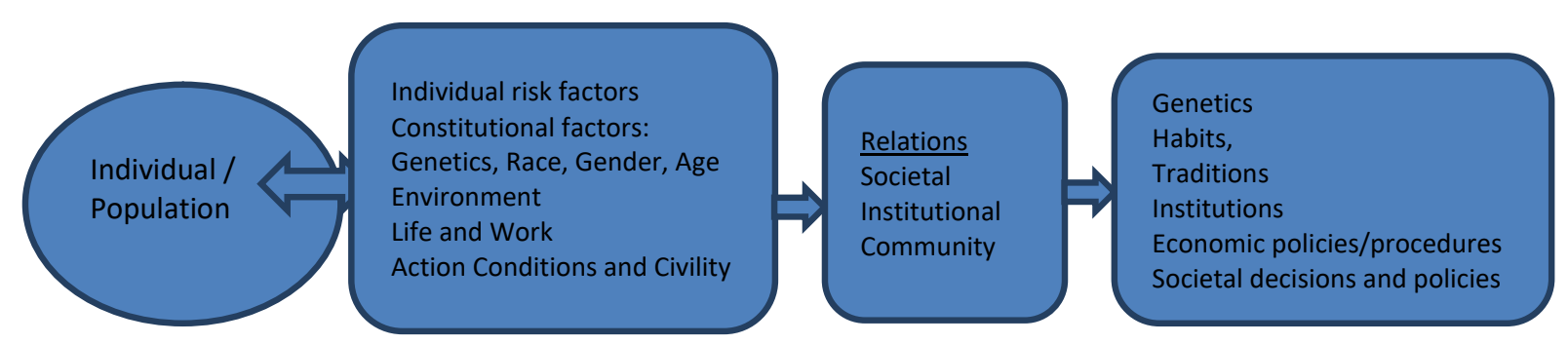

Fig. 1: The graphic representation of the socio-medical-economic model

In such a context, three levels quantify the health benefits:

- at the individual level (individuals' awareness on skills development and access to resources of any individual),

- community-based (health - related features of people 's backgrounds), and

- in a broader social-cultural way (e.g. social policies, religious social centres, unequal access to educational resources).

Education remains an important filtering mechanism that place individuals in certain societal contexts. As a driving force at every level, education has real implications in every decision-making aspect of each person's life - choosing a partner, a job, a health service, a social position in the community hierarchy.

In Romania, at least one third of children live in poverty (Gheorghiu, 2018), with considerable vital shortcomings. Each of these children lacks knowledge or financial resources appropriate to their normal study or health services. Consequently, they are permanently exposed to severe risks, the worst of which is the inability to leave this disadvantaged environment. Recent analyses of Eurostat (2018) fully confirm these conclusions. In its latest analysis of social indicators, Eurostat highlights Romania as the poorest country in the European space, with the largest poorer population accounting for $50 \%$ of the total population living and working in rural areas (Gheorghiu, 2018). As a result, children in these disadvantaged geographical areas are exposed to socio-economic and demographic disturbing factors. These have an important influence not only to their lives but also to the future of the country:

a) lack of a minimum level of education,

b) slight abuse of immorality, lack of the most elementary knowledge of hygiene and non-compliance with essential hygiene standards, 


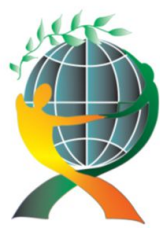

\author{
(online) $=$ ISSN $2285-3642$ \\ ISSN-L = $2285-3642$ \\ Journal of Economic Development, Environment and People \\ Volume 8, Issue 1, 2019 \\ URL: http://jedep.spiruharet.ro \\ e-mail: office jedep@spiruharet.ro
}

c) suffer from malnutrition and other illnesses that would normally have been eradicated for several decades, d) have an extremely low life expectancy without any prospects of living and decent work (Gheorghiu, 2018).

The evolution of the last years shows that the public medical services in Romania proved to be more and more limited and helpless in the face of the new demographic evolutions and labour market trends. Those are due:

a) to the decrease of the human resources from the medical staff, due to the option to temporarily or permanently residing in other states with highly professional medical systems,

b) to the dissolution of public clinics and hospitals due to lack of adequate infrastructure, authorizations and institutional accreditation, lack of adequate staff, old, used, inadequate facilities,

c) to the difficulties in collecting resources, due to the increased demands for free medical services and much more. Although many categories of population can benefit from free medical services, practically these very numerous social categories cannot access, if necessary, the medical services they are entitled to. The various reasons focus on the lack of knowledge of the theory, of the policy implementation mechanism, of the lack of proper management skills, of the impossibility to intelligent use of budgets or of alternative funding resources.

Beyond the many measures required to revive the two fundamental sectors of any democratic society the health and the education - the society is in high need to create new skills, new attitudes to use other resources, to define, implement and ensure decent human care conditions and equal access to all values and resources of the society.

\title{
Conclusion
}

The socio-medical-economic model presented here can provide a context for the many ways in which education is linked to our life experiences, including health outcomes. It come also up with support for understanding how educational outcomes are conditioned by the many social and environmental aspects we live in, and how they interact with our individual experiences and reward such values, at community level.

The model can become the foundation of a matrix where the new policy analysis, together with the robust financial decision, health education and societal investment will contribute to the modern transformation of our society.

\section{References:}

[1] Barbaresi, W.J., Katusic, S.K., Colligan, R.C.,Weaver, A.L. and Jacobsen, S.J., 2007. Long-term school outcomes for children with attention-deficit/hyperactivity disorder: a population-based perspective. J Dev Behav Pediatr., Aug, Vol.28(4), pp.265-73, https://www.ncbi.nlm.nih.gov/pubmed/17700078.

[2] Barnett, W. Steven and Belfield, Clive R., 2006. Early Childhood Development and Social Mobility. The Future of Children, Vol. 16, No. 2, Opportunity in America (Autumn), pp. 73-98, Princeton University, https://www.jstor.org/stable/3844792.

[3] Berkman, L.F., 1995. The role of social relations in health promotion, Psychosom Med., May-Jun, Vol.57(3), pp. 245-54, https://www.ncbi.nlm.nih.gov/pubmed/7652125.

[4] Center on Society and Health - CSH, 2015. Why Education Matters to Health: Exploring the Causes.February 13, Virginia Commonwealth University, https://societyhealth.vcu.edu/media/society-health/pdf/test-folder/CSH- 


\author{
(online) $=$ ISSN $2285-3642$ \\ ISSN-L = 2285 - 3642 \\ Journal of Economic Development, Environment and People \\ Volume 5, Issue 2, 2016 \\ URL: http://jedep.spiruharet.ro \\ e-mail: office jedep@spiruharet.ro
}

EHI-Issue-Brief-2.pdf.

[5] Conti, G. and Heckman, J.J., 2010. Understanding the early origins of the education-health gradient. Perspect Psychol Sci, Vol.5, pp.585-605, https://www.researchgate.net/publication/235412043_Understanding_the_Early_Origins_of_the_Education-Health_Gradient, https://www.ncbi.nlm.nih.gov/pmc/articles/PMC3129786/.

[6] Financial Express, 2018. You Will Live Longer If You Are Better Educated; Here's The Proof, FE Online, April 18, https://www.financialexpress.com/economy/want-to-live-longer-your-chances-are-more-if-you-get-highereducation-and-theres-proof-for-it/1136786/.

[7] Gheorghiu, Marcela, 2018. Sărăcia subminează educaţia, lipsa educaţiei blochează şansele copiilor la un viitor mai bun şi proiectul de dezvoltare a României, Tribuna Învăţământului; dec.10,

http://www.tribunainvatamantului.ro/saracia-submineaza-educatia-lipsa-educatiei-blocheaza-sansele-copiilorla-un-viitor-mai-bun-si-proiectul-de-dezvoltare-a-romaniei/.

[8] Goldman, D.P. and Smith, J.P., 2002. Can patient self-management help explain the SES health gradient?, Proc Natl Acad Sci, USA, Aug 6, Vol. 99(16), pp.10929-34. Epub 2002 Jul 24,

https://www.ncbi.nlm.nih.gov/pubmed/12140364.

[9] Kaplan, G.A., Wilson, Thomas, Cohen, R.D., Kauhanen, Jussi, Wu, Melien and Salonen, J., 1994. Social functioning and overall mortality: Prospective evidence from the Kuopio Ischemic Heart Disease Risk Factor Study, Epidemiology, Vol.5, pp. 495-500, https://www.ncbi.nlm.nih.gov/pubmed/7986863, https://www.researchgate.net/publication/15212105_Social_functioning_and_overall_mortality_prospective_ev idence_from_the_Kuopio_Ischemic_Heart_Disease_Risk_Factor_Study.

[10] Karlamangla, A.S., Singer, B.H. and Seeman, T.E., 2006. Reduction in allostatic load in older adults is associated with lower all-cause mortality risk: MacArthur studies of successful aging. Psychosom Med., May-Jun; Vol.68 (3), pp. 500-7, https://www.ncbi.nlm.nih.gov/pubmed/16738085.

[11] McEwen, B.S. and Stellar, E., 1993. Stress and the individual. Mechanisms leading to disease. Arch Intern Med., Sep 27, Vol.153 (18), pp. 2093- 101,https://jamanetwork.com/journals/jamainternalmedicine/articleabstract/617820 https://www.ncbi.nlm.nih.gov/pubmed/8379800.

[12] OECD/EU, 2018. Health at a Glance: Europe 2018: State of Health in the EU Cycle, OECD Publishing, Paris. https://doi.org/10.1787/health_glance_eur-2018-en.

[13] Olshansky, S.J., Antonucci, T., Berkman, L., Binstock, R.H., Boersch-Supan, A., Cacioppo, J.T., Carnes, B.A., Carstensen, L.L., Fried, L.P., Goldman, D.P., Jackson, J., Kohli, M., Rother, J., Zheng, Y. and Rowe, J., 2012. Differences in life expectancy due to race and educational differences are widening, and many may not catch up, Health Aff (Millwood), Aug, Vol.31(8), pp.1803-1813, doi: 10.1377/hlthaff.2011.046, https://www.researchgate.net/publication/230623955_Differences_In_Life_Expectancy_Due_To_Race_And_Edu cational_Differences_Are_Widening_And_Many_May_Not_Catch_Up https://www.ncbi.nlm.nih.gov/pubmed/22869659.

[14] Palczyńska, Marta and Świst, Karolina, 2018. Personality, cognitive skills and life outcomes: evidence from the Polish follow-up study to PIAAC, Large-scale Assessments, Education An IEA-ETS Research Institute Journal, Vol.6 (2), https://doi.org/10.1186/s40536-018-0056-z.

[15] Smedley, B.D. and Syme, S.L.,- ed., Institute of Medicine, (2000), Promoting health: intervention strategies from social and behavioral research, Washington DC, National Academies Press, 


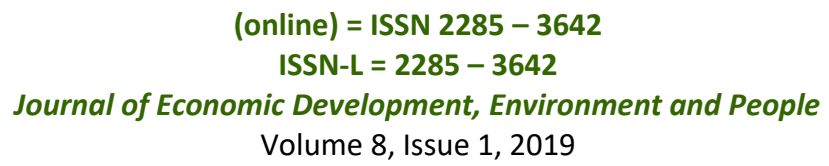

URL: http://jedep.spiruharet.ro e-mail: office jedep@spiruharet.ro

https://www.ncbi.nlm.nih.gov/pubmed/25057721

[16] Sobolewski, J.M. and Amato, P.R., 2005. Economic hardship in the family of origin and children's psychological well-being in adulthood. J Marriage Fam, Vol.67, pp.141-56, https://doi.org/10.1111/j.0022-2445.2005.00011.x

[17] Suhrcke, M. and de Paz Nieves, C., 2011. The impact of health and health behaviours on educational outcomes in high-income countries: a review of the evidence. Copenhagen, WHO Regional Office for Europe, http://www.euro.who.int/en/publications/abstracts/impact-of-health-and-health-behaviours-on-educationaloutcomes-in-high-income-countries-the-a-review-of-the-evidence 